POEMA

\title{
A PARTIR dOS SEUS OLHOS
}

\author{
FABRÍcio CORSALETTi
}

o desespero do coração aniquilado

aponta para o futuro quebradiço como louça

e o passado é um tempo transmudado em espaço inacessível

mas o futuro concebido na alegria do meu coração

fala aos seus olhos elementares

como os homens que prescindem da amizade se procuram

nesse futuro nascem seus olhos antecipados cresce o amor como peito quente de menino

a minha intimidade com a vida canta intacta 